Dr L David Lal

Assistant Professor (Political Science)

Department of Humanities \& Social Sciences

Indian Institute of Information Technology, Guwahati,

India

\title{
Anatomy of Caste Violence: The Question of Dignity, Honour and Justice in India
}

\begin{abstract}
The Constitution of India prescribes provisions to safeguard the lives of the Scheduled Castes. Special Acts are designed to address the existing challenges related to discriminatory practices and brutal violence against them by the dominant communities. The protective legislations have however seldom acted to restrain increasing display of cruelty against the historically marginalised. Mundane normalised violence compels them to question the authority of caste and functioning of the legal system in India. The persistence of caste-based violence highlights the inability of state and bureaucracy to create an order in society. It is, therefore, necessary to understand the nature of the social system, causes of violence against Dalits and the working of administrative and judicial machinery. This paper highlights a detailed analysis of caste violence occurred in 2006 in the northern state of Uttar Pradesh. It examines the usage of violence by the upper caste to maintain and re-produce the caste-based social order.
\end{abstract}

\section{Introduction}

In a remote village of Bura Bartara in Firozabad District of Uttar Pradesh, a young scheduled caste boy was brutally murdered by a group of upper-caste men on 12 June 2006. A national daily carried this news buried under other news items. As far as violence against scheduled castes are concerned this news was very ordinary. There are forty thousand cases reported each year against the erstwhile outcastes. Despite strict legal mechanisms working at a different level, rise in violence against the 'exceptional legal subjects' 1 forces us to visit the sociopolitical structures operate at the village level. One must understand the caste morality in practice and how it challenges the constitutional morality discussed by Ambedkar in the constituent assembly. According to Ambedkar, "Constitutional morality is not a natural sentiment. It has to be cultivated. We must realize that our people have yet to learn it. Democracy in India is only a top-dressing on an Indian soil which is essentially undemocratic."2 It was further articulated well in 'period of contradictions' before presenting the new constitution for independent India. Even after seven decades of independence scheduled castes are socially and economically unequal but remains politically equal. 3

Among the States in India, Uttar Pradesh has caste traditions that run deep into the social fabric. With a higher concentration of Scheduled Castes (Dalits) with 20.7 per cent in 2011, it has a

\footnotetext{
${ }^{1}$ Rao, Anupama (2010). Caste in Question: Dalits and the politics of Modern India, Permanent Black, New Delhi ${ }^{2}$ Ambedkar, 'Speech Delivered on 25 November 1949' in The Constitution and Constituent Assembly Debates, p. 174.

${ }^{3}$ Ibid.
} 
dubious distinction of having the maximum number of atrocities against Dalits. Uttar Pradesh has been the land of Bhakti, Adi-Hindu and Bahujan movement. It has churned a new identity to the oppressed communities. Recognition and dignity were the core philosophical attributes of these movements. Despite Uttar Pradesh being politically volatile, the society has largely remained unchanged, particularly in terms of dominance and suppression. 4 It saw caste and religious identities playing a decisive role not only in an individual's life but also the everyday matters of public life. Several attempts of resistance by the scheduled caste ended up as a group or individual violence over the Dalit community. Moreover, exploitation of one caste groups by another caste group in the name of the ritually superior or inferior leading to caste tensions, caste conflicts and atrocities by one caste against another.

\section{The (Ab) Normal Incidence}

A young boy from the scheduled caste community was murdered on 12 June 2006 . According to media reports, the boy was brutally killed by the upper caste men for participating in Kirtan (Hindu religious prayer). However, narratives varied on the ground. The incident is placed between three villages, place of incident (Bura Bartara), place of the victim (Nagla Madari) and place of alleged theft (Sarai Sheikh). Caste composition of these three villages varies exposing the functioning of caste respectively. Bura Bartara -a small village in Firozabad District, otherwise famous for its glassworks. This village has got 500 households with a population of more than 5000 people. Nearly 60 per cent of Bura Bartara population belong to Lodhi community (Other Backward Castes) and others belong to scheduled caste community such as Jatav, Dhobi, Teli, Valmiki, Chamar, Nai, Dhanak, Diwakar. Nagla Madari village is comprised of 137 households and a population of 1020 all of them belongs to the Jatav community (Scheduled Castes). However, the third village Sarai Sheikh has 78 per cent Muslim population and 21 per cent $\mathrm{OBC}$ and rest scheduled caste.

On the day of the murder, Beni Ram, former Gram Pradhan (village head), Nagla Madari village filed a complaint at Sirsa Ganj police station. It is after three days of constant pressure from media and Dalit civil society organisations the police registered an FIR No. 149/2006 at the same police station which is situated 3 miles away from the Bura Bartara village. The case was booked under Section 194/2006 Article 147 (guilty of rioting) Indian Penal Code 302 (Murder), 201 (Causing disappearance of evidence of the offence or giving false information to screen offender) and SC/ST (Prevention of Atrocities) Act 3 (2) V (commits any offence under the Indian Penal Code (45 of 1860) punishable with imprisonment for a term of ten years or more against a person or property on the ground that such person is a member of SCs or STs or such property belongs to such member, shall be punishable with imprisonment for life and with fine), IPC $120 \mathrm{~B}$ (1) Whoever is a party to a criminal conspiracy to commit an offence punishable with death, (2) imprisonment for life or rigorous imprisonment for a term of two years or upwards, shall, where no express provision is made in this Code for the punishment of such a conspiracy, be punished in the same manner as if he had abetted such offence.

According to the FIR, the victim Pramod (name changed), a daily wage earner at a brick kiln factory, after his work went to village Bura Bartara in the evening. He saw Kirtan organised by the Lodhi community and participated in the Kirtan. He took a Chimta (a long thin iron musical instrument) to play for the Bhajan (devotional song) but he was resisted by the

\footnotetext{
${ }^{4}$ According to the Annual Report of 2017 by the Ministry of Social Justice and Empowerment, Government of India, twenty districts in Uttar Pradesh are identified as atrocity prone districts under SC/ST (POA) Rules, 1995.
} 
members of Lodhi community.5 They challenged his presence and brutally assaulted him causing death. However, members of the victim's family stated, his arms and legs were broken. The brutality continued till midnight. He was lying unconscious with no help. Few men from the victim's community attempted to rescue him, however, could not stand the brute force of violent men. During the early hours of the next day, seeing him alive, the men from the dominant community tied his hands, loaded him on a cycle and took him to the main entrance of the village. They did not stop the display of gruesomeness. He was tied in an electric pole and gave him electric shock forcing him to take his last breath of life. Heavy police were deployed in Bura Bartara and Nagla Madari village for five days after the incident to avoid any re-emergence of social conflict.

Act of participating in the Kirtan and touching the musical instrument was perceived as disobeying caste norm by the upper caste men. Untouchability- the base of caste structure, is the worst form of oppression that often results in disagreements causing violence. Although rituality of caste has decreased over a period of time but has not ended. Subordination is a root of rituality 6 that was challenged by Pramod in this case. An attempt to access the ritual domain of upper-caste men invited a rupture of the normal prescribed in caste norms.7 However, the investigation report prepared by the police which was ordered by the former Superintendent of Police who deputed the Circle Officer as the primary investigating officer contained a different narrative. 8 The victim was a person with questionable character and often caught stealing others properties. Few days before the incident, victim stole a buffalo calf of an upper-caste from Bura Bartara village and sold it to a Muslim man from Sarai Sheikh village. After the news of stealing came to light the next day from the man who bought the calf, members of dominant Lodhi community reached Sarai Sheikh to claim the calf. The mob got violent and targeted the victim with rods and sticks. Later the victim died due to multiple injuries.

Surprisingly, the narrative provided by the investigation report matched the narration of the accused. During the investigation, police arrested 34 men from the Lodhi community. All the accused were sent to 20 to 28 days of police custody. This study interviewed some of the accused related to the case. According to them, 'victim was a drug addict who was involved in multiple stealing in the nearby villages. His involvement in stealing of the calf agitated few of us causing his death. We intended to teach him a lesson and not to kill him.' Both investigation report of police and interview of accused did not refer to the ritual cause of violence. Absence of specific caste angle from both narrations depicts the nexus between the police and the accused. Dalits often isolated from the larger narrative of violence. Their representation of facts is eliminated from the official version of the incident.

\footnotetext{
${ }^{5}$ Article 25(2) (b): provides that Hindu religious institutions of a public character shall be thrown open to all classes and sections of Hindus. This provision is relevant as some sects of Hindus used to claim that only members of the concerned sects had a right to enter their temples. For the purpose of this provision the terms Hindu includes Sikh, Jain and Buddhist.

${ }^{6}$ Mendelson, Oliver and Marika Vicziany (1998). The Untouchables: Subordination, Poverty and the State in Modern India, Cambridge University Press: Cambridge, pp.21-63

7 Balamurli Natarajan (2011), The Culturalisation of Caste in India-Identity and Inequality in a Multi-cultural Age, Routledge-California.

${ }^{8}$ As per clause 7 (1) of the Scheduled Castes and the Scheduled Tribes (Prevention of Atrocities) Rules, 1995, an offence committed under the Act shall be investigated by a police officer not below the rank of a Deputy Superintendent of Police. The investigating officer shall be appointed by the State Government / Director General of Police/Superintendent of Police after taking into account his past experience, sense of ability and justice to perceive the implications of the case and investigate it along with right lines within the shortest possible time.
} 
When the study further explored details of violence from the Sarai Sheikh village brought a different version about the victim. According to an eye witness to the case, a resident and brother of Gram Pradhan (village headman) praised the victim for being honest and hardworking. In his interview, he hinted the involvement of few upper-caste men from Sarai Sheikh village along with men from Bura Bartara. The accused attempted to present the incident between Dalits and Muslims. He further said the police deliberately failed to probe the case to unearth the facts, rather police were investigating the case from the accused perspective. Witness raised questions such as 'who provided rope to tie the victim?', 'how the Muslim's involvement is associated with the case?' 'why the kirtan version is jettisoned from the probe?' such questions were reduced to a matter of insignificance. Police were found aiding the upper caste men. The omission of participation of the victim in the religious ceremony diluted the case. Caste prejudice as a reason for the violence was replaced by theft in the charge-sheet that was filed after the completion of the investigation. All the 34 men were released on bail due to the absence of caste angle.

\section{Veil of Caste and Proceedings of Court}

According to Chapter IV, clause 14 every district must have a Special Court to provide speedy trial to the victims. Firozabad District does not have a Special Court prescribed by the SC/ST (POA) Act, 1989, however, the District Court is designated to conduct the cases under the special act. The case was trialled in court no. 5 and court no. 2 of the District Court. A public prosecutor was assigned to the victim's family as per clause 15 of SC/ST (POA) Act, 1989. Fear of losing legal battle, family members of the deceased authorised a private prosecutor too. Family members were subjected to frequent threats from the accused during trial. Intimidation for mutual compromise, withdrawal of the case, display of violence were common encounter. Judiciary dealt the matter as per the charge-sheet was filed. Caste was negated from judicial hearing. Any attempt to highlight the caste prejudice was ignored. New pieces of evidence to probe the murder were undermined. The case went on for 2 years and 15 days with routine hearing. A total of 30 to 40 hearings were conducted to deliver impartial justice however failed to include the victim's version of the incident. Many witnesses turned hostile due to intimidation, inability to commute for the hearing and cross-examination by the lawyer of the accused. On 5 October 2008, due to lack of evidence all the accused were acquitted. The jury did not find 'caste' as a motive behind the killing, nor there a conspiracy against the Dalits. Deliberative negligent behaviour of police during the investigation and filing of charge-sheet the motive of caste could not be established during the trial. Moreover, the constant challenge to secure lives compelled family members to receive the distorted judgment.

\section{Searching Harmony amidst Disharmony: Post Violent 'Caste' Society}

Caste villages in Indian society are ridden with disharmony. Constant social friction evaporates harmony from social and psychological imagery of Dalits. Structural oppression is a permanent feature of caste society. Discrimination, untouchability, denial of choice or access to spaces remain to operate even with adoption and implementation of special acts. Rejection of classified caste norms, in this case, Pramod's attempt to enter into the ritual domain of caste Hindu brought the blatant reality of caste-violence. Dhanda is employed often to discipline the marginalised within the caste system. The post violent caste society threatens, intimidate and force scheduled castes to live in constant fear. This incident of Bura Bartara has created a social and psychological impact among the scheduled caste community. Conflicts are mostly instigated with specific motives which are either socially, economically, or politically oriented. This case demonstrates the everyday struggle of scheduled caste lives in a social system. 
Witnessing structural, physical to procedural violence seems a quotidian experience. There is persistent enforcement of caste power by the dominant communities. It was organised mob violence against a non-compliant scheduled caste boy. Incidents such as these question MN Srinivas's argument on Obituary of Caste.9 Salient features of caste, touch, purity, endogamous, superiority not only present but thriving in a caste society. Violence is employed to hold and strengthen the traditional power in society. Upper caste Lodhi community desire to dominate not only their village but also the adjacent villages. Nagla Madari is a scheduled caste populated village which is economically and politically marginalized. The killing of Pramod added to the social disharmony. The rift between communities challenges the promise of harmonious society provided by the special acts. The SC/ST (POA) Act, 1989 was implemented to prevent and punish the violators of social harmony, however, the law failed to deliver justice to the victim's family. It has caused deeper psychological trauma and fear among scheduled caste population in the village. Acquittal of all the 34 accused have not only hampered the morale of the victim's family but also scheduled caste population. 'Ab kahan jayenge?' where will we go now? a perennial question of scheduled castes who experience a lack of support from the court. The relation between the upper caste and scheduled caste have estranged. Upper caste men, particularly the accused released after the trial walk with no remorse of inhuman act.

\section{Protecting the Past of Caste: Dignity, Honour and Justice in a violent caste society}

The incident of Bura Bartara has highlighted some key features of caste society and its violent forms. Moreover, it has revealed the inability of administrative and judicial structure to provide hope of a just society to the scheduled castes. Firstly, both constitutional provisions and specials acts for scheduled castes were created to ensure dignity, honour and justice, however, they continue to suffer multiple forms of violence. The inability of administrative machinery such as Superintend of Police, District Magistrate, Nodal Officer, Special Officer, Special Public Prosecutor, Special Court etc. to prevent violence questions the intention of these machinery. The conviction rate is not beyond 24 per cent. 10 Secondly, the caste is witnessing a gradual change both in villages and minds of scheduled castes. Changing nature of caste is due to the persistent struggle by Dalits to claim their space. The continued search for dignity and honour have resulted in their assertion. To counter the growing assertion, the collaborative forces of upper-caste men perpetrating violence against them. The traditional base of the caste system and the advent of modernity together have produced a different 'caste-class structure' in society. A new coalition between caste-class and bureaucracy-judiciary has created a 'culture of control' in society.

Thirdly, even though the scheduled castes making alternative livelihood mostly working as migrant labourers distant from the control of the village system still immediate economic dependence on upper caste in few villages made them vulnerable to systemic oppression. Quotidian experiences of Dalit lives in the caste society such as Bura Bartara highlights the compromise and negotiation for economic livelihood as most of the scheduled caste in the village work in the farmland of upper castes. Fourthly, there is visible upper-caste solidarity to protect the past of the caste. The organised mob violence against scheduled caste is for losing grip over the caste structure. Modernity is eroding rituality of caste- protection of rituality of caste have shown signs of the emergence of upper-caste men. Fifthly, due to the threat by the

\footnotetext{
${ }^{9}$ Srinivas MN. (2003). 'An obituary on caste as a system', Economic and Political Weekly, Vol. 38, Issue, 5, pp. 455-59

${ }^{10}$ Crimes in India, (2018), National Crime Record Bureau, Government of India, Delhi.
} 
upper caste men, police do not register the formal complaint without the intervention of Dalit civil society organisations. Delay in the FIR, delays the investigation and filing of chargesheets. Meanwhile, plenty of evidence goes missing and the victim's family become more vulnerable. Sixthly, in this case, it was found that investigation was led by the upper caste accused men. Narrative of the upper caste and filed investigation report omitted the caste motive of the violence. Police visit the village headman and register the case. Mostly, police do not even bother to reach to the victim's family. Seventhly, the special court and designated court acts on the investigation and charge sheet filed by the police. The social status of the accused and the role of upper caste play a significant role to prevent justice from reaching to scheduled castes. The false investigation report misleads the court procedure. Despite the public prosecutor's efforts, seldom attention is given to Dalit narrative. Inability to visit courts periodically due to distance, the threat from upper caste make eyewitnesses turn hostile. Financial assistance is given to witness and victim's family under the rules of the SC/ST (POA) Act, 1995 is never attained in this case.

Lastly, a significant issue that needs attention is post-violent society. How does caste violence impact the lives of Dalits? What support mechanism is provided by the administration? Does the recognition of violence and rehabilitation solve the issue of caste violence without proper justice delivered to the scheduled castes? What is the everyday interaction between victim and perpetrator?

\section{Summary}

United Provinces of Agra and Awadh, after independence Uttar Pradesh for the past ten centuries, had politically occupied an important place in Indian history. Its vast, fertile Gangetic plains attracted invaders from west and central Asia. In many ways, the history of Uttar Pradesh became the history of North India. The introduction of democratic politics after 1947 has further increased its importance as it elects one out of every six members to the Indian parliament.11 Low caste status is ascribed by birth but, the forces of modernisation like modern education, industrialisation, and better means of communication have made the lower castes aware of their rights and social deprivations. The greater consciousness among the lower castes has resulted in social contradictions leading to social tensions between upper castes and Dalits. Moreover, exploitation of one caste groups by another caste group in the name of the ritually superior or inferior leading to caste tensions, caste conflicts and atrocities by one caste against another.

Here there is no denying that the repeated violence against Dalits by the upper castes is deeply rooted in the traditional caste system apart from the economic and political differences. With the introduction of land reforms and the abolition of the zamindari system, the 'landlordism' became insecure.12 Democracy and adult franchise have affected the caste system in numerous ways. The vote is regarded as the symbol of power, and all castes have become politically conscious. The numerical strength became the basis of power during the elections.13 The argument of Rajni Kothari says caste has entered the field of politics with kith and kin enjoying

\footnotetext{
11 K.D. Purane, (2000). Untouchability and the law: The ground reality, Gyan Publishing House, New Delhi, p.174.

12 A.K. Singh Art. (2001). "Social Structure and Development Process: A Study of Scheduled Castes of Uttar Pradesh" in ed. Vol. Social Change in Post independents India by A.K. Lal and S. Sami Ahemad, p.142

${ }^{13}$ R. Jayaraman, (1981). Caste and Class: dynamics of inequality in Indian society, Hindustan Pub. Corporation, New Delhi, pp27-28
} 
the power and making politicisation of caste.14 With the emergence of different castes in politics, the caste system got polarised and gave rise to the bilateral structure of caste politics.

Apart from the introduction of politicised values, changes have taken place in society through the impact of education, technology, and urbanisation. Amidst the process of modernisation and economic development a fairly large section of population witness multiple types of social inequality, unrest, discontent resulting in a growing degree of agitation, movement, tensions, conflicts and atrocities. Fernando while quoting Beteille argues that the 'increased visibility' of Dalits in the socio-political arena due to creation of political party for themselves in Uttar Pradesh, in return provided heavy cost in the form of a rise in atrocities against Dalits. 15

Time and again, below the surface of domesticated, normalised and benign facts of caste reality such as caste endogamous marriages, there are also instances of 'brutal' 'abnormal' caste violence against the scheduled castes. The later event compels us to re-think and re-visit the fundamental basis of our understanding of caste. If we accept the domesticated, normalised understanding of caste as a normal practice then we also need to examine the role of blatant caste violence in our society. This paper exposes the blatant reality of caste violence against Dalits. This violence is a tool to produce and re-produce the existing caste structure. The assertion of 'upper castes' to secure and maintain its ' historically privileged position' is increasing.

\footnotetext{
${ }^{14}$ Rajni Kothari, (1970). (ed.) Caste in Indian Politics, Orient Blackswan: New Delhi.

${ }^{15}$ Franco, Fernando, (2002). (ed.) , Pain and Awakening: The Dynamics of Dalit identity in Bihar Gujarat,and Uttar Pradesh, Indian Social Institute: New Delhi, p-16
} 